\title{
Contemporary Urban Missions and Reflecting Reality in Deprivation of Civil Areas in Indian Cantonments - A Pragmatic View
}

\author{
Amit CHATTERJEE* \\ *Corresponding author \\ ${ }^{1}$ School of Planning and Architecture, Department of Urban and Regional Planning, Bhopal, Madhya Pradesh, INDIA \\ $\triangle$ amit.chatterjee@spabhopal.ac.in (1) https://orcid.org/oooo-0002-8204-6082 \\ DOI: 10.24193/JSSP.2021.2.01 \\ https://doi.org/10.24193/JSSP.2021.2.01
}

K e y w o r d s: cantonment, civilians, urban missions, welfare, deprivation, India

\begin{abstract}
A B S T RA C T
The contemporary urban schemes were launched around five years ago by the National Government to create more inclusive cities and offer a decent quality of life to urban residents. But in reality, the civilian areas of Cantonments are grossly overlooked from the benefits of such welfare schemes. There are 52 notified civil areas in Indian Cantonments with a population of 2.08 million, according to the 2011 census. The Cantonment Act, 2006 (by repealing the Cantonment Act, 1924) empowered Cantonment Boards to act as 'deemed to be a municipality 'to receive grants and implement government welfare schemes, including the provision of 24 types of infrastructure and services to its residents. The present research reviews the provisions and coverage of contemporary urban missions, including Smart Cities, and highlights civilian areas of the cantonments as deprived urban areas. Besides the non-implementation of contemporary urban welfare schemes, issues like the age-old colonial infrastructure, revenue crunch through taxes and non-taxes, absence of development plan, lack of inter-jurisdictional coordination etc., need to be addressed. The present research will act as an input for policymakers to understand the problems of civilian areas, nature, and extent of welfare scheme implementation, and also suggest the necessary changes required at the policy level.
\end{abstract}

\section{INTRODUCTION}

In September 2015, the United Nations formulated 17 Sustainable Development Goals (SDGs), with their 169 targets set for inclusive and equitable development, leaving no one behind. The SDGs aims are broad, interdependent and should be achieved globally by all United Nations member states by 2030 . Realising the need to achieve the goals and targets of SDGs, the Government of India has launched ambitious urban missions during the financial year of 2015-2016. These urban welfare missions are intended to promote opportunities for all and universal coverage at all levels: from National to State (province) to local community level (NITI Aayog, 2019). The present research tries to link the contemporary urban development in India, ongoing urban missions, including smart cities and issues related with civilian areas of Cantonments. The Cantonments of India established at strategic places, generally far-ends from the native towns or cities, form a distinct colonial settlement structure due to their discrete settlement character, heritage legacy, sociocultural and demographic attributes. Political and military necessities are the two prime factors that influenced the site location. The motive of careful segregation was evident two-fold, initially between cantonment and the native towns, while, post-mutiny of 1857, between Indian and European troops, in which case the separate troop's quarter was the prime motive of such segregation. Also, within Cantonments, military 
and civil areas were usually separated (King, 1976; Nangia, 2004; Howard, 2013). Over time, due to rapid urbanization and spatial extension of cities, Cantonments have developed either as part of nearby large cities or its immediate adjoining areas, as one of the prime suburbs (Gangwar, 2016), with isolated pockets (civilian areas) within it. In this context, metropolitan cities like Delhi, Kanpur, Lucknow, etc., are no exception. Currently, Cantonments like Pune Cantonment in Maharashtra, Jabalpur Cantonment in Madhya Pradesh, Lucknow Cantonment in Uttar Pradesh etc., represent separate constituencies in the State Legislative Assembly (Vidhan Sabha).

In the post-colonial era, neo-liberal dominance is evident in the domains of urban studies, urban planning, political geography and critical geography (Naylor et al., 2018; Jazeel, 2019). In his research, Wright (2013) highlighted the neo-liberal waves in Australia, United States, and the United Kingdom. A study by Vesalon and Crețan (2019) emphasized how Timişoara city in western Romania had strived hard to neoliberal urban development through city branding. There are several studies worldwide dealing with the ideas of the 'right to the city' for all social groups (Purcell, 2002; Creţan and O'Brien, 2020), social mixing and social imaginaries (Taylor, 2002) and spatial segregation (Bolt et al., 2010; Cheshire, 2009). A study by Creţan et al. (2020) revealed that racial stigmatisation of Roma people by existing urban policies perpetuates racial stigma. Also, a recent article by $\mathrm{M}^{\prime}$ erein'e-Berki et al. (2021) on Szeged city highlighted the lived experience of deprived people during desegregation.

Post-1990s, there was growing literature on post-colonial theory and inequalities between states and people (Naylor et al., 2018). The spatial segregation of the cantonments from the city is evident through gated enclosures and controlled entrances. Cantonments were initiated as purely military areas, but later, due to the indispensable growth of trade and commerce, transport and communication, a large number of civilian communities have been attracted to these areas. These civil areas grew as segregated neighbourhoods that had no direct connection with the troops. The spatial layout of the cantonment has distinct segregated civil areas, which brings tensions at the local level (Government of India, 2015). The Cantonments Act of 2006 focused on imparting greater democratisation, including the framework for implementation of the Development Plan and Town Planning Scheme (local level) for economic development and social justice. However, the absence of a Development Plan, building bye-laws, and lack of public participation resulted in tensions at the local level (Government of India, 2018b).

The term deprivation indicates 'a standard of living or a quality of life below that of the majority in a particular society', often associated with inadequate access to resources (Herbert, 1975, p. 362), inequitable distribution of services (You, 2016; Dadashpoor et al., 2016; Rocha et al., 2017; Li et al., 2019) and unfair distribution of benefits of development (Egawa, 2012; Atuguba, 2013). Many researchers have recently relooked smart cities beyond digital technology innovation and focused on inclusive smart cities (Malhotra et al., 2021; Visvizi and Perez del Hoyo, 2021; Wang et al., 2021) with the support of Democratization (Praharaj and Han, 2019). The benefit of the urban welfare missions launched by the Indian Government should reach all sections of urban citizens, including people residing in the notified civil areas. Consequently, in the era of massive urban reform initiatives and 'global enthusiasm for smart cities' (Khan et al., 2018, p. 80), the term 'Cantonment', as a colonial suburb, cannot be neglected in debates and discussions within academia, policy, and practice. A significant literature gap exists on the post-colonial development of Indian Cantonments, particularly welfare issues and how to mobilize resources to provide services and support to civilian populations.

This paper consists of five sections, and following introduction, section 2 focuses on the material and method used for the present research. Section 3 presents the mission component, approach, timeline, coverage, and financial aspects of contemporary urban missions in India. Section 4 highlights the spatial spread and population distribution of Cantonments. Section 5reviews the contemporary urban missions' guidelines to trace civil areas of the Cantonment under missions' coverage and traces the present state of participation and development initiatives. Section 6 critically reviews the financial health and legal concerns. Finally, section 7 suggests a few pragmatic steps for drafting such welfare missions in the future.

\section{MATERIAL AND METHOD}

\subsection{Research questions}

The current research focused on the following two research questions:

i) What are the provisions mentioned in the urban mission guidelines to extend the welfare benefits to the residents of the Cantonments?

ii) Whether the Cantonments residents are getting the benefits or are deprived of the ongoing 'Central Government schemes of social welfare' as mentioned in Clause 10.2(b) of the Cantonment Act, 2006?

\subsection{Source literature and limitations}

This paper focuses mainly on secondary literature sources such as government reports, policies, 
plans, notifications, etc., available for the public. Apart from reviewing the mission guidelines, cantonment act, and policies, this paper draws significantly from empirical reading of the government information sources in the last decade, including Press Information Bureau notifications, Performance Audit reports, Standing Committee reports, Public Accounts Committee reports, Cantonment City Development Plans, newspaper articles, etc. Although the research questions mentioned in this study offer an approach to understand the natural justice of 'leaving no one behind' with respect to the 17 SDGs and urban missions' targets, the study encounters some limitations. Due to the COVID-19 pandemic and security issues, the primary data collection methods and stakeholders' consultation was not explored. Another limitation was the impossibility to understand the financial health status over time in cantonments of different population size. Although the broader issues related to civilian areas are common, the micro level issues may vary depending on the population size of cantonments in India. Future studies can be carried out by considering the previously mentioned limitations.

\section{RESULTS AND DISCUTIONS}

\subsection{Contemporary urban missions}

The Government of India, under the Ministry of Housing and Urban Affairs (MoHUA) has launched new flagship urban missions for sustainable urbanization, which include Smart Cities Mission, Atal Mission for Rejuvenation and Urban Transformation (AMRUT), Urban Transport, Heritage City Development and Augmentation Yojana (HRIDAY), Pradhan Mantri Awas Yojana - Urban (PMAY-U), Housing for All (Urban) Swachh Bharat Mission Urban (SMB-U), and Deendayal Antyodaya Yojana National Urban Livelihood Missions (DAY-NLUM) during the financial years of 2014-2015 and 2015-2016 (Chatterjee and Chattopadhyay, 2020). To perform a comparison of contemporary urban missions in terms of mission components, the approach followed a timeline and geographical coverage, as mentioned in Table 1.

Table 1. Contemporary urban schemes in India (2015-present).

\begin{tabular}{|c|c|c|c|c|c|c|}
\hline Features & \multicolumn{6}{|c|}{ Urban missions } \\
\hline \multirow[b]{2}{*}{$\begin{array}{l}\text { Mission } \\
\text { Components }\end{array}$} & AMRUT & Smart City & SBM-Urban & HRIDAY & $\begin{array}{l}\text { PMAY - } \\
\text { Urban }\end{array}$ & DAY-NULM \\
\hline & $\begin{array}{l}\text { Infrastructure } \\
\text { improvement } \\
\text { with reform } \\
\text { agenda }\end{array}$ & $\begin{array}{l}\text { Smart } \\
\text { infrastructure } \\
\text { solutions for } \\
\text { better quality } \\
\text { of life to } \\
\text { citizens }\end{array}$ & $\begin{array}{l}100 \% \text { open } \\
\text { defecation, } \\
\text { free status, } \\
\text { and solid } \\
\text { waste } \\
\text { management }\end{array}$ & $\begin{array}{l}\text { Sustainable } \\
\text { Growth of } \\
\text { Selected } \\
\text { Heritage } \\
\text { Cities }\end{array}$ & $\begin{array}{l}\text { Housing for } \\
\text { all by the } \\
\text { year } 2022\end{array}$ & $\begin{array}{l}\text { Gainful self- } \\
\text { employment } \\
\text { and skilled } \\
\text { wage } \\
\text { employment } \\
\text { for urban } \\
\text { poor }\end{array}$ \\
\hline Approach & Step-by-step & $\begin{array}{l}\text { Compact area } \\
\text { development }\end{array}$ & Target-based & $\begin{array}{l}\text { Integrated } \\
\text { urban } \\
\text { planning with } \\
\text { heritage } \\
\text { conservation }\end{array}$ & Target-based & Target-based \\
\hline Timeframe & 5 years & 5 years & 5 years & 5 years & 7 years & $7-8$ years \\
\hline $\begin{array}{l}\text { Territorial } \\
\text { coverage }\end{array}$ & $\begin{array}{l}500 \text { cities } \\
\text { including } \\
\text { Cantonment } \\
\text { Boards } \\
\text { (civilian } \\
\text { areas) }\end{array}$ & 100 cities & $\begin{array}{l}\text { All cities } \\
(>4300)\end{array}$ & 12 cities & $\begin{array}{l}\text { All cities } \\
(>4300)\end{array}$ & $\begin{array}{l}\text { All cities } \\
(>4300)\end{array}$ \\
\hline
\end{tabular}

A recent report of MoHUA mentioned that a total of Indian Rupees (INR) 3,26,545 crore (60.47 billion USD) central assistance was approved during the last five years (2014-2019) under these contemporary urban missions. The maximum financial assistance was provided to PMAY-U (37.69\%), followed by Urban 
Transport (27.8\%), AMRUT (15.29\%), Smart Cities Mission (14.68\%), SBM-U (4.46\%), DAY-NLUM (0.65\%) and HRIDAY (0.65\%) schemes (MoHUA, 2019a).

\subsection{Cantonment areas in India}

The Cantonments are divided into three broad areas: the purely military area, the bungalow area, and the civilian pockets. The regimental bazaars, usually called Sadar Bazaar, British India Bazaar (BI Bazaar), and Native India Bazaar (NI Bazaar), are common markets for civilians and defence personals and their dependents. The Cantonment Act, 2006, defines civil areas as 'inhabited largely by civil population' and presently, out of the 61 Cantonments in India (Fig. 1), distributed among five army commands, 52 Cantonments have notified civil areas.

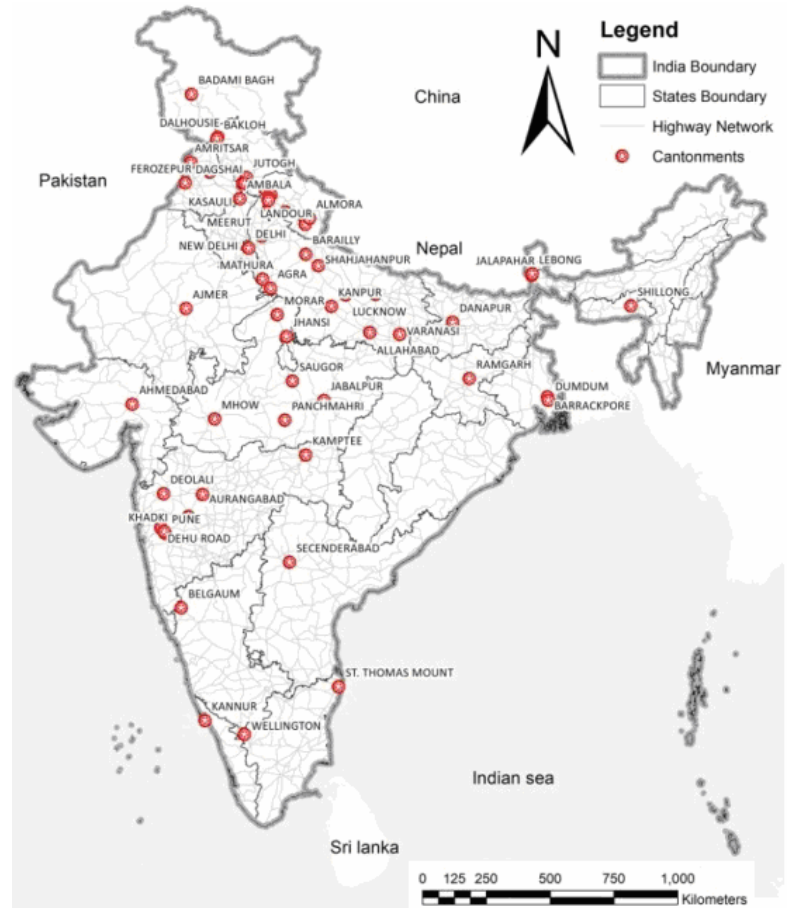

Fig. 1. Cantonment areas in India (source of data: Census of India, 2011).

A total of 2.08 million individuals reside in these cantonments as per the 2011 census (Table 2).

Table 2. Class-wise population distribution in Indian Cantonments.

\begin{tabular}{l|rr} 
Population class size & Population & Percentage \\
\hline Less than 5,000 & 31,073 & 1.49 \\
$5,000-25,000$ & 289,328 & 13.90 \\
$25,000-50,000$ & 454,997 & 21.87 \\
$50,000-100,000$ & 868,693 & 41.75 \\
$100,000-200,000$ & 218,885 & 10.52 \\
200,000 and more & 217,910 & 10.47 \\
Total & $2,080,886$ & 100 \\
\multicolumn{1}{|c}{ Source of data: Census of India, 2011. }
\end{tabular}

Out of the total population in Indian Cantonments, around $42 \%$ of the people reside in the category of cantonment areas with 50,000 to 100,000 people. Further, Secunderabad cantonment has the maximum share of the population ( 0.217 million) among India's cantonments.

\subsection{Reflecting reality in participation (or deprivation)}

Under section 62 of the Cantonment Act 2006 (No. 41 of 2006 dated $18^{\text {th }}$ December 2006), the mandate of the Cantonment Board is to provide effective and efficient 24 types of infrastructure and services to the civilian population residing within cantonments. The Cantonment Act (2006) mentions that:

Every Board shall be deemed to be a municipality under clause (e) of article $243 P$ of the Constitution for the purposes of-- (a) receiving grants and allocations; or (b) implementing the Central Government schemes of social welfare, public health, hygiene, safety, water supply, sanitation, urban renewal and education (Section 10 [2]).

Currently, the Cantonment areas are facing a variety of problems such as 'serious gap between the public aspirations for civic amenities and the actual amenities available' (Government of India, 2011a), 'unauthorised constructions' (Government of India, 2011b; Ministry of Defence, 2018), 'encroachment of defence lands by civilians' (Ministry of Defence, 2018, p. 120), shortage of resources and at times depends on State Government or Local Military Authorities for the essential services' (Government of India, 2014), issues related with land and properties (Government of India, 2015; Government of India, 2020), etc. So far, as gaining benefits from the urban welfare schemes are concerned, they continued till 2013-2014; through a press release, the Government clarified that the 'Central welfare scheme like Jawaharlal Nehru National Urban Renewal Mission (JNNURM), Indira Awas Yojana and National Slum Development Program had not been extended to any Cantonment Board' (Government of India, 2012). Even the 'eligible Cantonment Boards remained deprived' to receive financial grants and benefits from JNNURM, Swarna Jayanti Sahari Rozgar Yojana (SJSRY), and other welfare schemes (Comptroller and Auditor General of India, 2015, p. 23). In the upsurge of cities in the Global North for the application of 'smart solutions' in urban management, the Indian National Government has launched the ambitious Smart Cities Mission in June 2015 for the duration of the following five years (2015-2016 to 20192020). A hundred cities are supposed to be selected in the first phase. The major thrust is to apply information technology-based smart solutions to promote highquality urban infrastructure and services, and it 
eventually to improve the quality of life of urban citizens. As per Smart Cities Mission guidelines, the selected smart cities must suggest two types of interventions in the form of 'pan-city (city-wide) development' and 'area-based development'. The National Government promised to contribute with Rs. 48,00o crore (USD 6.7 billion) funding over five years (yearly average of Rs. 100 crores $(134,846,30$ USD) for each of the selected cities) and State (provincial) Government/Urban Local Bodies are also expected to contribute with an equal amount, on a 'matching basis,' resulted in total funding of nearly Rs. 1,00,00o crore $(134,846,300,00$ USD), which will be available for the hundred smart cities development (MoUD, 2015a, p. 13). The National Government announced a total of 99 cities as winners of smart cities challenge competition in different rounds/track from January 2016 to January 2018, and many of the selected cities are having adjoining cantonments, with notified civilian areas. According to the Census of India 2011, a total of 7.92 lakhs (0.792 million) people reside in these Cantonments that are located in the adjoining selected smart cities (Census of India, 2011a) (Table 3). Also, in those selected smart cities, the planned integration between city and cantonments is grossly overlooked. In many cantonments, residents have complained about poor civic infrastructure and services (Government of India, 2018b; Outlook Magazine Sept 08, 2019). As a result of the non-coverage, the Cantonment Boards are unable to receive funding and extend the benefits to their residents under the Smart Cities Mission initiatives.

Table 3. Round-wise selection of Smart Cities and its adjoining Cantonments.

\begin{tabular}{|c|c|c|c|c|}
\hline Date & $\begin{array}{l}\text { Round/ } \\
\text { Track }\end{array}$ & $\begin{array}{l}\text { No. of } \\
\text { selected } \\
\text { cities }\end{array}$ & $\begin{array}{c}\text { Selected Smart Cities having adjoining } \\
\text { Cantonments }\end{array}$ & $\begin{array}{l}\text { Total population } \\
\text { of adjoining } \\
\text { Cantonments- } \\
2011 \text { (millions) }\end{array}$ \\
\hline $\begin{array}{l}28 \text { January } \\
2016\end{array}$ & Round 1 & 20 & 03 (Jabalpur, Ahmedabad, Pune) & 0.173 \\
\hline 24 May 2016 & Fast track & 13 & 02 (Lucknow, Dharmashala (Kasyol)) & 0.075 \\
\hline $\begin{array}{l}20 \text { September } \\
2016\end{array}$ & Round 2 & 27 & $\begin{array}{l}09 \text { (Agra, Kanpur, Varanasi, Ajmer, Aurangabad, } \\
\text { Amritsar, Jalandhar Gwalior (Morar), Nagpur } \\
\text { (Kamptee)) }\end{array}$ & 0.316 \\
\hline 23 June 2017 & Round 3 & 30 & $\begin{array}{l}07 \text { (Allahabad, Saugor, Jammu, Dehradun } \\
\text { (Clement Town), Danapur (Patna), Srinagar } \\
\text { (Badmibagh), Jhansi (Babina)) }\end{array}$ & 0.197 \\
\hline $\begin{array}{l}19 \text { January } \\
2018\end{array}$ & Round 4 & 9 & 01 (Bareilly) & 0.030 \\
\hline
\end{tabular}

As far as cantonment record and land management are concerned, in last decade, the Ministry of Defence has initiated many initiatives towards the management of assets, including land record management, computerization of land records, unauthorized constructions, a centralized database of the encroached defence land, preparation of buildingbye laws and development plans etc. The Cantonment Act (2006) states that the Chief Executive Officer shall, with the approval of the Board, initiate to prepare a spatial plan for land use, which should include: (a) earmarking zones for residential, institutional, commercial and other activities; and (b) improvement schemes for areas considered sub-standard on account of narrowness of streets, poor lighting, poor ventilation or irregular line of buildings in a street (Section 233[1]).

The absence of a development plan/master plan, including a land use plan and development control regulation, resulted in haphazard development within the Cantonment area. In recent years, the
Ministry of Defence has initiated the preparation of development plans in cantonment areas. Also, the Government has launched some of the information technology-based smart initiatives, including i) system for solving public complaints 'Samadhan', and ii) computerization of defence land records through 'Raksha Bhoomi' software (Government of India, 2011a; Comptroller and Auditor General of India, 2015) for the welfare of the civilians and land management. In 2018, the Ministry of Defence launched an initiative to offer smart solutions in the seven selected cantonments, namely Delhi, Ambala, Deolali, Ferozepur, Meerut, Pune, and Secunderabad, similarly to the10o Smart City Mission initiatives (Economic Times, Jan 03, 2018). So, there are initiatives taken by the Ministry of Defence towards smart solutions and upgrading civic amenities, including cantonment land and record management.

The AMRUT mission was initiated in 2015 for infrastructure creation and 'universal coverage of infrastructure' focusing on water supply, sewerage, storm water drains, pedestrian and public transport 
facilities, green spaces, and recreation centres, which would eventually improve the citizens' quality of life. A total of 500 cities have been selected under the AMRUT mission. The Cantonment Boards (civil areas), with more than one lakh (o.1 million) population as per Census 2011, are covered by the AMRUT mission (MoUD, 2015b, p. 6). As a result, out of 52 Cantonments with notified civil areas, only three Cantonments, namely Secundrabad (0.217 million people), Delhi (o.110 million people), and Kanpur (o.108 million people), have met the population eligibility criterion (o.1 million people). Even those three eligible Cantonments failed to participate and, as a result, were deprived of benefits under the AMRUT mission. It is to be mentioned here that, under the Cantonment Act 2006, the Cantonment Board has been empowered to act 'deemed to be a municipality' for promoting quality infrastructure and services from its age-old colonial infrastructure and services to the residents.

To reduce the gap between public aspirations and the available civic infrastructure and amenities, the Cantonment Boards have implemented Municipal Solid Waste (Management and Handling) Rules, 2000 in the cantonments, including door to door waste collection, ban on the use of polythene bags, the prohibition on open defecation, spreading awareness about sanitation and cleanliness, etc. (Government of India, 2011a). As mandated in Swachh Bharat Mission (Urban), all Cantonment Boards have participated in Swachh Survekshan 2018 initiatives, and for that, 'Cantonment Board Ranking' is considered a separate section of awards (Government of India, 2018c). In recent Swachh Surveksh, an assessment ranking announced by the Ministry of Housing and Urban Affairs, Delhi Cantonment Board, Meerut Cantonment Board, and Jutogh Cantonment Board, have been awarded as the first three front runners of the 'Cleanest Cantonment Board'. Further, Amritsar Cantonment Board, Jalandhar Cantonment Board, Ahmednagar Cantonment Board, and Dalhousie Cantonment Board have been honoured as the best Cantonment Boards categories of 'Citizen Feedback,' 'Innovation and Best Practices,' and 'Solid Waste Management' (MoHUA, 2019b, p. 194). As a result of the Swachh Survekshan assessment exercise, there is growing competitiveness among Cantonment Boards for providing the best service delivery to their residents.

\subsection{Certain basic financial concerns}

The Cantonment Boards significantly depend on Central Grant-in-aid due to the limited scope for trade and business activities, non-recovery of property taxes, non-revision of property taxes every five years, and the tiny scope of recovery on account of services rendered to private individuals. Some 17 Cantonment
Boards including Dehradun, Lucknow, Meerut, Ramgarh, Ahmednagar, Barrackpore, Clement town, Danapur, Kasyol, Panchmarhi, Ranikhet, Shilong, Wellington, Chakrata, Lansdowne, Dalhousie, and Jalapahar, were subject to the fiscal analysis performed by the Comptroller and Auditor General of India, for the period 2009-2010 to 2013-2014, which reveals hope and concern regarding the financial health of these selected Cantonment Boards . Besides the narrow gap between the flow of receipts and expenditure, in three Class I Cantonments (population ranges from 2,500 to 10,000) that include Dehradun, Lucknow, and Meerut, the total expenditure surpasses the total receipts heads (Comptroller and Auditor General of India, 2015, p. 29). A report of the Defence Standing Committee on 'Demand for Grants' for the year 2018-19 endorsed the financial crunch for the maintenance of the Cantonment Boards (Ministry of Defence, 2018, p. 120), and, accordingly, recommended to the Government for the additional funds under Grant-in-aid to meet the requirements (Ministry of Defence, 2019, p. 40). Recent Expert Committee on problems faced by civilian areas of the Cantonments highlighted the matters related to the Cantonment Boards' financial status, land tenures, building bye-laws, democratizing cantonment governance, and proposals for smart cantonments (Government of India, 2020).

The bulk of properties in the Cantonments are central or state government-owned, on which municipal service charges are supposed to be levied by the Cantonment Board as under Section 109 of the Cantonments Act 2006. The non-recovery of annual service charges from government department-owned properties discloses Cantonment Boards' higher dependency on Grant-in-aid from the Defence Ministry (Comptroller and Auditor General of India, 2015; Government of India, 2020). Further, civilian areas within the Cantonments are located in isolated pockets, spread over large areas. As a result, both construction and operation and maintenance costs for providing civic amenities are quite high (National Commission to review the working of the Constitution, 2001).

In States like Maharashtra, after the introduction of Local Body Tax (LBT) on 1 April 2013, there was no revenue-sharing agreement between the Cantonment Board and City Municipal Corporation. Further, with the introduction of The Goods and Services Tax (Compensation to States) Act, 2017, taxes like LBT include in GST, which was earlier collected by the Cantonment Boards (Mukherjee, 2020). Recently, the Ministry of Defence has released service charges to five financially weak cantonments to improve their fiscal health (Times of India, 10 February 2020). The non-receipt of welfare grants under contemporary missions has resulted in a situation where immediate attention is required from the Government for the welfare of the civilians. Only two contemporary 
missions, namely, AMRUT (includes civil population of more than one lakh in 2011 census) and Swachh Bharat Mission - Urban (covers all statutory town including Cantonment Boards), has incorporated Cantonments under the coverage of the missions. According to the Indian census, statutory towns are defined as urban areas, regardless of their demographics, declared under the law, and have local bodies like Municipal Corporations, Municipalities, Cantonment Boards, Notified Town Area Committees, Town Panchayats, etc. (Census of India, 2011b). It is worth noting that the Government has not accepted the suggestions received for the merger of civilian areas with adjoining local bodies because Cantonment Boards are already functioning as 'deemed municipalities' (Government of India, 2015). But in reality, the Cantonments have not been recognized as 'Municipal Authorities' under States Tax Laws and State Municipal Laws (Ministry of Defence, 2015). In the present state of urban governance and city planning, city and cantonments are considered two separate governing entities. Interjurisdictional coordination and planned integration are now inevitable for the better welfare of the people.

\section{CONCLUSIONS}

The urban form and settlement structure of the Cantonment still carries the image of colonial legacy and has a rich history and heritage value. Apart from the vernacular residential structure, there are many heritage structures such as St Patrick's Cathedral (builtin 1850) of Pune Cantonment, St Paul's Church (consecrated in 1857) of Ambala Cantonment etc. that have immense heritage potentials. Further, Cantonments like Barackpore Cantonment of West Bengal (established in 1765) and Danapur Cantonment (established in 1765) etc., have more than two centuries of their rich and glorious past. Therefore, it is worthwhile to declare these Cantonments as 'special areas' and propose 'area-based development' intervention under the Smart Cities mission. The proposed intervention could ensure transformation from age-old colonial infrastructure to high-quality smart infrastructure and services to the residents. The special zoning for redevelopment or retrofitting can be planned in the civilian areas under section 46 (notification), section 64 (discretionary functions of the Boards), section 251 (power to make bye-laws), and section 260 (group housing scheme) of the Cantonment Act, 2006. Also, the Government can preserve the heritage character of Cantonments and provide financial support to the heritage infrastructure projects under the HRIDAY scheme.

Recently, the National Government has planned to reap the benefits of the AMRUT scheme (renamed as AMRUT-plus) and identified the rest of 3500 towns (with a population of less than 0.1 million) in the second phase of the AMRUT mission (Times of India, July 27, 2018). The proposed AMRUT-plus mission can integrate all cantonments as a separate category of mission cities for active participation. Housing for All (Urban) and DAY-NLUM schemes primarily target the development of urban poor households by providing them housing and employment opportunities. Extending the coverage of such social welfare schemes to civilian areas can ensure a better living environment for poor people. The Government may consider extending the coverage of contemporary urban schemes or drafting the guidelines of the future urban schemes and include Cantonment Board on the list as a 'Municipal Authority' so that the residents of the cantonments can benefit from the government welfare schemes. The recent COVID-19 pandemic crisis has once again brought up to discussion the need to empower Urban Local Bodies, including Cantonment Boards, to control the outbreak. Nevertheless, all Cantonment Boards in India are managing the essentials of civilians' life such as hygiene, public health, safety, water supply, sanitation, roads, housing, and education.

The Cantonment Board generates revenue through meagre taxes and other fees. There are alternatives to increase this revenue. The board can also organise weekly markets, which will also earn rents. Proper planning strategy, as recommended above, shall ease the establishment of paid parking, theatres, cinemas, community hall, stadiums, gymnasia etc., which will also generate revenue. Further, in March 2017, the Ministry of Defence issued a notification for the revision of lease rent by $100 \%$ after the expiry of every 10 years on a compounding basis. Rent will be fixed based on the use of the site, classified as residential, commercial, and lucrative. The lease rent for residential sites is equal to normal Standard Table of Rent (STR) rates, for commercial sites twice the STR rate and lucrative sites four times the STR rates as per extant instruction. The same can be incorporated on the expiry of the rent lease, and it will help in generating additional revenue for the Cantonment Boards. Cantonment Boards should reassess the property tax once every five years, as highlighted in the Cantonments Bill 2020 section 76(2), in order to incorporate the new properties that have been developed since the last previous assessment as well as the hitherto un-assessed properties, i.e., the properties that were left unassessed in the last evaluation exercise (The Cantonment Bill, 2020). Regular assessment of property tax will add to the flow of receipts and improve the fiscal profile of the Cantonment Boards.

Cantonment areas are divided into wards, and ward representatives are elected through elections, usually every five years. As a civic administrative body, Cantonment Board consists of local elected members and military members, ex-officio members, and one 
representative of the district magistrate. In such a context, more dialogue and trust-building with elected representatives can help achieve the development objectives in the long run. Also, the preparation of a Development Plan for the Cantonment areas, mainly focusing on civilian areas, can resolve the problems such as infrastructure inequality, informality, congestion, housing shortage etc., in a more planned and rational manner.

Urban welfare missions are intended to promote 'opportunities for all' and 'universal coverage,' but by excluding the civilian areas of the Cantonments from the mission coverage, the broader aim remains unfulfilled. The trajectory of 'inclusive development' has raised concerns about the non-integration of cantonments with selected Smart Cities Mission cities. Accordingly, it urges the policymakers to revisit the mission guidelines for institutionalizing and implementing social welfare schemes in the Cantonment civilian areas. The following suggestions are proposed for the civilian areas of the Cantonments: (i) prepare development plan including development control regulations, (ii) declare Cantonments as 'Smart Cantonments' similarly to the 100 Smart City Mission initiatives, (iii) include civilian areas of the cantonments under Housing for All (Urban) and DAYNLUM mission coverage, (iv) eliminate the population criteria (one lakh population) listed under the AMRUT mission coverage and include all civilian areas, (v) increase public participation and dialogues with local people that will bring down tensions at the local level. Such a developmental approach will offer civilians a decent quality of life and develop trust between civilians and Cantonment Boards. The future scope of the research includes preparing a framework for inclusive smart cantonments and theorising urban politics in Indian cantonments.

\section{REFERENCES}

Atuguba A. R. (2013), Equality, non-discrimination and fair distribution of the benefits of development. OHCHR. Chapter 7 . URL: https://www.ohchr.org/Documents/Issues/Developme nt/RTDBook/PartIIChapter7.pdf.

Bolt G., Phillips D., van Kempen R. (2010), Housing policy, (de)segregation and social mixing: An international perspective. Housing Studies, 25(2), 129-135. DOI: https://doi.org/10.108o/02673030903564838.

Census of India (2011a), Primary census abstract, Office of the Registrar General \& Census Commissioner. Government of India.

Census of India (2011b), Provisional population totals urban agglomerations and cities-data highlight. URL: http://censusindia.gov.in/2011-provresults/paper2/data_files/India2/1.\%20Data\%20Highl ight.pdf. Accessed on 12.12.2020.
Chatterjee A., Chattopadhyay R. N. (2020), Problems and Policies of Metropolitan Growth in India. In: Satellite Towns in Neo-metropolitan Development in India. Advances in 21st Century Human Settlements. Springer, Singapore. URL: https://doi.org/10.1007/978-981-15-1502-6_2

Cheshire P. (2009), Policies for mixed communities: Faith-based displacement activity? International Regional Science Review, 32(3), 343-375. DOI: https://doi.org/10.1177/0160017609336080.

Comptroller and Auditor General of India (2015), Union government (defence services) army, ordnance factories and defence public sector undertakings. Report no. 44 of 2015. URL: https://cag.gov.in/uploads/download_audit_report/20 15/Union_Compliance_Defence_Army_Ordnance_Re port_44_2015_1_o.pdf. Accessed on 10.03.2020.

Creţan R., Málovics G., Berki B. M. (2020), On the perpetuation and contestation of racial stigma: Urban Roma in a disadvantaged neighbourhood of Szeged. Geographica Pannonica, 24(4), 294-310, DOI: 10.5937/gp24-28226.

Creţan R., O'Brien T. (2020), Corruption and conflagration: (in)justice and protest in Bucharest after the Colectiv fire. Urban Geography, 41:3, 368-388, DOI: https://doi.org/10.1080/02723638.2019.1664252.

Dadashpoor H., Rostami F., Alizadeh B. (2016), Is inequality in the distribution of urban facilities inequitable? Exploring a method for identifying spatial inequity in an Iranian city. Cities, 52 (159-172). DOI: 10.1016/j.cities.2015.12.007.

Economic Times (2018), Government to introduce smart solutions in 7 cantonments. January 03. URL: https://economictimes.indiatimes.com/news/defence/ government-to-introduce-smart-solutions-in-7cantonments/articleshow/62356447.cms. Accessed on 05.01.2020.

Egawa A. (2012), The Uneven Distribution of the Benefits of Growth Impeding the Expansion of Asia s MiddleIncome Stratum. NIRA Monograph Series, No. 35. URL: https://www.nira.or.jp/pdf/e_monograph35.pdf.

Accessed on 10.02.2020.

Gangwar P. (2016), Cantonments, military stations \& cities, Tangled Perspectives. wordpress.com, 11 December.

URL: https://poojagangwaro209.wordpress.com/2016/12/11 /cantonments-and-military-stations-in-india/.

Accessed on 02.02.2020.

Government of India (2011a), Civil population in cantonments. Press Information Bureau, Ministry of Defence, Government of India, 19 December. URL: https://pib.gov.in/newsite/PrintRelease.aspx?relid=78 952. Accessed on 02.01.2021.

Government of India (2011b), Illegal construction in Secunderabad cantonment. Press Information Bureau, Ministry of Defence, Government of India, o3 August. URL: 
https://pib.gov.in/newsite/PrintRelease.aspx?relid=73 828. Accessed on 02.01.2021.

Government of India (2012), Cantonment Boards. Press Information Bureau, Ministry of Defence, Government of India, 10 December. URL: https://pib.gov.in/newsite/PrintRelease.aspx?relid=90 277. Accessed on 02.01.2021.

Government of India (2014), Resources shortage in Cantonment Boards. Press Information Bureau, Ministry of Defence, Government of India, 1o February. URL:

https://pib.gov.in/newsite/PrintRelease.aspx?relid=10 3293. Accessed on 02.01.2021.

Government of India (2015), Problems of people in Cantonment Boards. Press Information Bureau, Ministry of Defence, Government of India, 24 July. URL:

https://pib.gov.in/newsite/PrintRelease.aspx?relid=12 3693. Accessed on 02.01.2021.

Government of India (2016a), Government announces first batch of 20 smart cities from 11 States and Delhi. Press Information Bureau, Ministry of Housing \& Urban Affairs, Government of India, 28 January, $2016 . \quad$ URL: https://pib.gov.in/newsite/printrelease.aspx?relid=135 889. Accessed on 02.01.2021.

Government of India (2016b), Lucknow tops fast track competition; 13 more smart cities announced. Press Information Bureau, Ministry of Housing \& Urban Affairs, Government of India, 24 May 2016. URL:

https://pib.gov.in/newsite/PrintRelease.aspx?relid=14 5587. Accessed on 02.01.2021.

Government of India (2016c), Amritsar tops the list of 27 new smart cities. Press Information Bureau, Ministry of Housing \& Urban Affairs, 20 September. URL:

https://pib.gov.in/newsite/PrintRelease.aspx?relid=15 0941. Accessed on 02.01.2021.

Government of India (2017), 30 more smart cities announced; takes the total to 90 so far. Press Information Bureau, Ministry of Housing \& Urban Affairs, 23 June. URL: https://pib.gov.in/newsite/PrintRelease.aspx?relid=16 5855. Accessed on 02.01.2021.

Government of India (2018a), Silvassa tops the list of winner cities--Erode, Diu, Biharsharif, Itanagar \& Kavaratti selected in round 4 of smart cities--Bareilly, Moradabad \& Saharanpur in UP also selected-99 smart cities selected so Far. Press Information Bureau, Ministry of Housing \& Urban Affairs, Government of India, $19 \quad$ January. URL: https://pib.gov.in/newsite/PrintRelease.aspx?relid=175 750. Accessed on 02.01.2021.

Government of India (2018b), Problems in cantonment areas. Press Information Bureau, Ministry of Defence, Government of India, 28 March. URL:
https://pib.gov.in/newsite/PrintRelease.aspx?relid=17 8115. Accessed on 02.01.2021.

Government of India (2018c), Prime Minister Narendra Modi attributes success of Swachh Bharat mission to the enthusiastic participation of people across the country. Press Information Bureau, Ministry of Housing \& Urban Affairs, Government of India, 23 June. URL:

https://pib.gov.in/Pressreleaseshare.aspx?PRID=153637 3. Accessed on 02.01.2021.

Government of India (2020), Expert Committee on Cantonments. Press Information Bureau, Ministry of Defence, Government of India, 18 March. URL: https://pib.gov.in/newsite/PrintRelease. $a s p x$ ?relid=20 0380. Accessed on 02.01.2021.

Herbert T. D. (1975), Urban Deprivation: Definition, Measurement and Spatial Qualities. The Geographical Journal. 141(3), 362-372. DOI: https://doi.org/10.2307/1796471

Howard S. (2013), City planning in India under British rule. Economic \& Political Weekly, 26 January, 48(4), 53-61. URL: https://www.epw.in/system/files/pdf/2013_48/o4/Cit y_Planning_in_India_under_British_Rule.pdf.

Accessed on 05.01.2020.

Jazeel T. (2019), Postcolonialism. $1^{\text {st }}$ Edition. Routledge. London. ISBN: 9781315559483 (e-book).

Khan S., Persis T., Marie-Helene Z. (2018), Mission impossible-defining Indian smart cities. Economic \& Political Weekly, LII(49),80-88 15 December, URL: https://www.epw.in/journal/2018/49/review-urbanaffairs/mission-impossible.html. Accessed on 05.01.2020.

King A. D. (1976), Colonial urban development: culture, social power and environment. $1^{\text {st }}$ Edition.. London: Routledge and Kegan Paul. ISBN-10: 0415611660

Li Z., Wei H., Wu Y., Su S., Wang W., Qu C. (2019), Impact of community deprivation on urban park access over time: Understanding the relative role of contributors for urban planning. Habitat International, 92, October, 102031, DOI: 10.1016/j.habitatint.2019.102031.

Malhotra C., Manchanda V., Bhilwar A, Basu A. (2021), Designing inclusive smart cities of the future: the Indian context. In: Vacca J R. (eds) Solving Urban Infrastructure Problems Using Smart City Technologies, Handbook on Planning, Design, Development, and Regulations, First Edition, Elsevier, 631-659. DOI: 10.1016/B978-0-12-816816-5.00029-2. Méreiné-Berki B., Málovics G., Creţan R. (2021), "You become one with the place": Social mixing, social capital, and the lived experience of urban desegregation in the Roma community. Cities, 117, 103302. DOI: https://doi.org/10.1016/j.cities.2021.103302.

Ministry of Defence (2018), Demands for grants (2018-19) - Standing committee on Defence (2017- 
2018), Army, Navy and Air Force (demand no. 20), Forty first report, March, 2018. URL: http://164.100.47.193/lsscommittee/Defence/16_Defe nce_41.pdf. Accessed on 05.01.2020.

Ministry of Defence (2019), Action taken by the government on the observations/ recommendations contained in the fortieth report (16th LokSabha) on 'demands for grants of the Ministry of Defence for the year 2018-19 on general defence budget, Border Roads Organisation, Indian Coast Guard, Military Engineer Services, Directorate General Defence Estates, Defence Public Sector Undertakings, Welfare of Ex-Servicemen, Defence Pensions, Ex-Servicemen Contributory Health Scheme (demand nos. 19 and 22), Forty sixth report, Standing committee of Defence (2018-2019), January, 2019.

URL: http://164.100.47.193/lsscommittee/Defence/16_Defe nce_46.pdf. Accessed on 10.03.2020.

Ministry of Law and Justice (2017), The goods and services tax (compensation To states) act, 2017, no. 15 of 2017, $12 \quad 12$ April. URL:http://www.cbic.gov.in/resources//htdocs-

cbec/gst/gst-compensation-to-statesact.pdf;jsessionid=10CDD54D4BoCF6D272BA5BoF57 E68C5E. Accessed on 12.12.2020.

MoHUA (Ministry of Housing and Urban Affairs) (2019a), Transforming urban landscape 20142019, Ministry of Housing and Urban Affairs, Government of India, New Delhi. URL: http://mohua.gov.in/upload/5c7fafooeac57UT\%20Boo k1.pdf. Accessed on 05.01.2021.

MoHUA (Ministry of Housing and Urban Affairs) (2019b), Swachh Survekshan-2019, Ministry of Housing and Urban Affairs, Government of India, New Delhi. URL: https://swachhsurvekshan2020.org/Images/SS2019\%2 oReport.pdf. Accessed on 05.01.2021.

MouD (Ministry of Urban Development) (2014), Guidelines for Swachh Bharat Mission (SBM), Ministry of Urban Development, Government of India. URL: http://swachhbharaturban.gov.in/writereaddata/SBM _Guideline.pdf. Accessed on 10.02.2020.

MouD (Ministry of Urban Development) (2015a), Smart city mission statement and guidelines.Ministry of Urban Development, Government of India, New Delhi. URL:

http://smartcities.gov.in/upload/uploadfiles/files/Sma rtCityGuidelines(1).pdf. Accessed on 10.02.2020.

MouD (Ministry of Urban Development) (2015b), AMRUT- mission statement and guidelines, Ministry of Urban Development, Government of India, New Delhi. URL:

http://amrut.gov.in/upload/uploadfiles/files/AMRUT \%20Guidelines\%20(1).pdf. Accessed on 10.02.2020.

Mukherjee S. (2020), Compensation to Cantonment Boards for revenue loss on account of GST, Economic \& Political Weekly, January 11, LV(2),15-18. URL:
https://www.epw.in/system/files/pdf/2020_55/2/CM _LV_1_110120_Sacchidananda_Mukherjee.pdf.

Accessed on 10.02.2021.

Nanjia A. (2004), British colonial architecture: towns, cantonments and bungalows. boloji.com, 12 September. URL: https://www.boloji.com/articles/1008/britishcolonial-architecture-towns-cantonments-ampbungalows. Accessed on 10.02.2020.

National Commission to review the working of the Constitution (2001), Empowering and strengthening local self-government in cantonments. A Consultation Paper, New Delhi. URL: http://legalaffairs.gov.in/sites/default/files/Empoweri ng\%20and\%20Strengthening\%2olocal\%20selfgovernment\%20in\%20Cantonments.pdf. Accessed on 10.02.2020.

NITI Aayog (2019), Localising SDGs early lessons from India 2019. National Institution for Transforming India.

URL:

http://niti.gov.in/writereaddata/files/LSDGs_July_8_ Web.pdf . Accessed on 24.03.2021

Naylor L., Daigle M., Zaragocin S., Ramírez M. M., Gilmartin M. (2018), Interventions: Bringing the decolonial to political geography. Political Geography, 66, 199-209.

DOI:

https://doi.org/10.1016/j.polgeo.2017.11.002.

Outlook Magazine (2019), Ambala cantonment civilians pine for smart cantonment. o8 September. URL:

https://www.outlookindia.com/newsscroll/ambalacantonment-civilians-pine-for-smart-

cantonment/1614156. Accessed on 05.03.2020.

Praharaj S., Han H. (2019), Cutting through the clutter of smart city definitions: A reading into the smart city perceptions in India. City Culture \& Society, 18, 100289, DOI: 10.1016/j.ccs.2019.05.005.

Purcell M. (2002), Excavating Lefebvre: The right to the city and its urban politics of the inhabitant. GeoJournal, 58, 99-108. DOI: https://doi.org/10.1023/B:GEJO.ooooo10829.62237.8f. Rocha V., Ribeiro AI., Severo M., Barros H., Fraga S. (2017), Neighbourhood socioeconomic deprivation and health-related quality of life: A multilevel analysis. PLoS ONE 12(12): e0188736. DOI: 10.1371/journal.pone.0188736.

Taylor C. (2002), Modern social imaginaries. Public Culture, 14(1), 91-124. DOI: https://doi.org/10.1215/08992363-14-1-91.

The Cantonment Act (2006), The Cantonment Act, No 41 of 2006, Ministry of Defence, Notification No. S.R.O. 15(E), dated $18^{\text {th }}$ December, Gazette of India, Extraordinary, Part II, sec. 3(i). URL: https://indiacode.nic.in/handle/123456789/2066?view _type=browse\&sam_handle $=123456789 / 1362$.

Accessed on 04.02.2020.

The Cantonment Bill (2020), The Cantonments Bill, 2020. Ministry of Defence. URL: 
https://www.mod.gov.in/sites/default/files/Cantonme ntsAct20.pdf. Accessed on 10.03.2021.

Times of India (2018), BJP invokes Atal Bihari Vajpayee, plans to expand AMRUT to smaller towns. Lucknow News, Times of India July 27. URL: https://timesofindia.indiatimes.com/city/lucknow/bjpinvokes-atal-bihari-vajpayee-plans-to-expand-amrutto-smaller-towns/articleshow/65162926.cms. Accessed on 04.02.2020.

Times of India (2020), Defence ministry gives Rs $6.5 \mathrm{cr}$ service charges to cantt board. Pune Times, Times of India, February 10. URL: https://timesofindia.indiatimes.com/city/pune/defenc e-ministry-gives-rs-6-5cr-service-charges-to-canttboard/articleshow/74051294.cms. Accessed on 02.01.2021.

You H. (2016), Characterizing the inequalities in urban public green space provision in Shenzhen, China. Habitat International. 56, 176-180. DOI: 10.1016/j.habitatint.2016.05.006.
Vesalon L., Crețan R. (2019), "Little Vienna" or "European Avant-Garde City?" Branding Narratives in a Romanian City. Journal of Urban and Regional Analysis, 11(1), 19-34. DOI:10.37043/jura.2019.11.1.2.

Visvizi A., Perez del Hoyo R. (2021), Smart Cities and the UN SDGs. First Edition. Elsevier - Health Sciences Division, Philadelphia, United States. ISBN 9780323851510 (hbk).

Wang C., Steinfeld E., Maisel J. Kang B. (2021), Is your smart city inclusive? Evaluating proposals from the U.S. Department of Transportation's Smart City Challenge. Sustainable Cities and Society, 74, 103148, DOI: https://doi.org/10.1016/j.scs.2021.103148

Wright I. (2013), Are we all neoliberals now? Urban Planning in a neoliberal era. '49th ISOCARP Congress. URL:

http://www.isocarp.net/data/case_studies/2412.pdf. Accessed on 30.09.2021 